\title{
Indonesian Journalism in the Era of Information Disruption
}

Jurnalisme Indonesia di Era Disrupsi Informasi

\section{Eko Sumardi, \\ Indah Suryawati²}

\section{INSTITUTION}

Universitas Budi Luhur

Indonesia

\section{PHONE}

\section{EMAIL}

1eko.mardi@gmail.com indah.suryawati@budiluhur.ac.id

\section{DOI}

https://www.doi.org/

10.37010/prop.v2i1.446

\section{PAPER PAGE}

15-31

PROPAGANDA is a Journal of Communication Studies which is publish twice a year on January and July. PROPAGANDA is a scientific publication media in the form of conceptual paper and field research related to communication studies. It is hoped that PROPAGANDA can become a media for academics and researchers to publish their scientific work and become a reference source for the development of science and knowledge.

\begin{abstract}
Fenomena jurnalisme online menuntut sebagian penyedia konten berita di media konvensional mengubah dirinya menjadi multiplatform. Ini bertujuan agar mampu bertahan dalam persaingan industri media. Tak heran, sebagian besar media berita konvensional yang masih bertahan saat ini memiliki situs di internet. Beberapa hanya mengikuti konten dari perusahaan induk, namun beberapa yang lain hanya menyediakan materi tambahan. Situs-situs yang berkaitan ini beroperasi dengan standar praktik dan profesionalisme yang sama seperti yang dilakukan oleh induk perusahaannya. Bisa dikatakan jurnalisme memasuki suatu masa yang disebut masa disrupsi. Metode dalam tulisan ini didasarkan pada metodologi kajian kepustakaan (library research) dengan menggunakan analisis deskriptif. Hasil penelitian menjelaskan bahwa masa disrupsi adalah masa ketika perubahan terjadi sedemikian tidak terduga, bersifat mendasar dan hampir menyentuh semua sendi kehidupan masyarakat. Dan kehadiran jurnalisme online telah merevolusi pemberitaan di mana kecepatan menjadi faktor utama. Berita bukan lagi peristiwa yang 'sudah berlangsung', tetapi menjadi peristiwa yang 'sedang berlangsung' yang patut disiarkan oleh media. Beberapa fitur dalam jurnalisme online justru disebut sebagai ragam penyebab dari terjadinya pengikisan idealisme dan kredibilitas dalam jurnalisme online. Dampak teknologi internet menyebabkan media berita online mengalami revolusi radikal yang membuatnya berbeda dengan jurnalisme di media massa pada umumnya.
\end{abstract}

The phenomenon of online journalism requires that some providers of news content in conventional media transform themselves into multiplatform. It aims to be able to survive in the competition of the media industry. Not surprisingly, most of the conventional news media that still survive today have sites on the internet. Some only follow content from the parent company, but some others only provide additional material. These related sites operate to the same standards of practice and professionalism as their parent company does. It could be said that journalism is entering a time called a period of disruption. The method in this article is based on library research and using descriptive analysis. A period of disruption is a time when change occurs so unexpectedly, is fundamental and touches almost all joints of people's lives. And the presence of online journalism has revolutionized news where speed is a major factor. News is no longer an 'already ongoing' event, but an 'ongoing' event that should be broadcast by the media. Some features in online journalism are actually cited as a variety of causes of the erosion of idealism and credibility in online journalism. The impact of internet technology caused the online news media to undergo a radical revolution that made it different from journalism in the mass media in general.

\section{KEYWORD}

disrupsi informasi, jurnalisme online, jurnalisme konvensional

information disruption, online journalism, conventional journalism 


\section{PROPAGANDA}

\section{PENDAHULUAN}

Hadirnya media online berbasis digital di Indonesia membuat industri media mengalami perubahan yang sangat signifikan dari waktu ke waktu. Bahkan saat ini hampir seluruh media cetak sampai media elektronik pun mau tidak mau menghadirkan berita dalam bentuk online, e-paper dan live streaming. Hal tersebut dilakukan seiring perkembangan zaman yang serba digital seperti saat ini, di mana zaman dahulu segala jenis media massa dikelola oleh organisasi dan manajemen yang mandiri, namun saat ini seluruh media berlomba-lomba memanfaatkan sistem digital yang tengah menjadi primadona di kalangan masyarakat luas.

Kita melihat media mainstream seperti Kelompok Kompas Gramedia (KKG) yang sudah mememiliki Harian Kompas ternyata mendirikan Kompas.com dan Kompas TV. Begitu pula Tempo Inti Media pemilik Majalah Tempo pun mendirikan Tempo.co dan Tempo TV (live streaming). Kelompok Media Indonesia Grup yang awalnya membangun Harian Media Indonesia, dalam perkembangannya mendirikan Metro TV dan mediaindonesia.com. Jawa Pos Group yang sebelumnya kuat dengan Jawa Pos Network News (JPPN) akhirnya mendirikan Jawa Pos TV dan jawaposnews.com, meski terbilang terlambat dibanding media besar lain.

Kondisi tersebut sudah diungkapkan teoritikus konvergensi media Henry Jenkins (2006) yang memberikan batasan konvergensi sebagai proses penyatuan yang berlangsung secara terus-menerus dan terjadi di antara berbagai aspek media seperti industri, teknologi, konten hingga khalayak. Itu terjadi secara terus menerus. Burnett and Marshall (2003) memaknai konvergensi sebagai penggabungan industri media, telekomunikasi, dan juga komputer yang kemudian menjadi sebuah bentuk yang bersatu dan berfungsi sebagai media komunikasi dalam bentuk digital. Tampaknya kedua definisi tersebut sejalan dengan fenomena yang ada saat ini, di mana aspek teknologi digital dalam industri media menjadi tuntutan utama di tengah-tengah perkembangan industri media di Indonesia. Penyatuan berbagai platform media tersebut menjadi salah satu strategi perusahaan media agar konten berita bisa terpublikasikan ke banyak platform media dengan biaya yang sama atau lebih rendah (Dwyer, 2010).

Pandangan terkait konvergensi juga diungkapkan Jenkins (2006). Ia melihat konvergensi media sebagai sebuah proses yang belum usai dan tidak mengarahkannya kepada proses penggantian media konvensional dengan media digital. Namun, konvergensi media lebih merupakan proses interaksi antara berbagai bentuk dan platform media (dalam Ashari, 2019).

Perkembangan teknologi digital mendorong terciptanya peningkatan jumlah media berita online dalam lima tahun terakhir dibanding dengan media berita konvensional seperti surat kabar, majalah, radio, dan televisi. Data terakhir dari Dewan Pers (2019) menyebutkan bahwa jumlah media di Indonesia mencapai 47.000. Dari jumlah tersebut, sebanyak 43.803 media adalah media online, sementara sisanya adalah media konvensional yaitu media cetak (2.000) serta media elektronik radio (674) dan televisi (523) (dewanpers.or.id, 2021) Tentunya di tahun 2021, angka tersebut mengalami kenaikan. Pemaparan data tersebut bila dijadikan sandaran dalam memetakan media online yang ada di Indonesia, maka bisa dilihat bagaimana perkasanya sekaligus betapa rawannya keberadaan media online ini, karena data tersebut akan terus bertambah seiring berjalannya waktu.

Fenomena tersebut tak hanya terjadi di Indonesia. Di Amerika Serikat, tingkat sirkulasi surat kabar memperlihatkan tren menurun dalam dua dekade terakhir. Dampaknya, pertumbuhan jumlah pelanggan melambat sekalipun masih ada pelanggan surat kabar dalam format digital, tetapi jumlahnya masih belum sebanding dengan penurunan tajam di surat kabar berlangganan. Di sisi lain, pendapatan iklan surat kabar juga mengalami penurunan drastis yaitu dari sekitar \$49 miliar pada tahun 2006 menjadi \$18 miliar pada tahun 2016 (Bartel, 2018). Kondisi tersebut berakibat pada pekerjaan jurnalis surat kabar masuk ke dalam daftar 
pekerjaan terburuk di Amerika Serikat, karena bergaji rendah dan stres kerja yang tinggi (Doyle, 2018).

Nasib media cetak dan elektronik di Indonesia tak berbeda jauh. Secara perlahan media massa berbasis cetak dan elektronik sudah mulai dikesampingkan atau kalau tidak ingin dikatakan mulai ditinggalkan. Sebagian masyarakat, terutama kalangan milenial lebih memilih memenuhi kebutuhan informasinya melalui media online maupun media sosial. Hanya dalam satu genggaman gawai, mereka bukan hanya mendapatkan informasi tetapi juga bisa melakukan banyak hal.

Menurut survei, masyarakat saat ini mengakses informasi melalui social media sebanyak 76 persen, televisi 59,5 persen dan portal berita online 25,2 persen (Cakrawala.co, 30 Juli 2021). Penetrasi penguna internet juga disajikan dalam laporan perusahaan media asal Inggris, We Are Social, yang bekerjasama dengan Hootsuite, merilis laporan ' Digital 2021: The Latest Insights Inti the State of Digital '. Laporan yang diterbitkan pada 11 Februari 2021 tersebut, menyatakan bahwa pengguna internet di Indonesia tercatat mencapai 202,6 juta dengan penetrasi 73,7 persen. Di mana rata-rata orang Indonesia mengakses internet per hari rata-rata 8 jam 52 menit melalui perangkat mobile maupun personal computer (kompas.com, 23 Februari 2021). Tahun 2020 saja, Indonesia berada di bawah Meksiko, Argentina, Thailand, Kolombia, Brazil, Afrika Selatan, dan Filipina yang tidak disangka menempati urutan pertama negara yang paling lama mengakses internet dengan total waktu 9 jam 45 menit (kumparan.com, 5 Februari 2020).

Riset perusahaan Informasi dan Pengukuran Global Nielsen juga menyatakan, pembaca media online di Indonesia sudah lebih banyak dibanding pembaca media cetak. Jumlah pembaca media online mencapai 6 juta orang, sedangkan pembaca media cetak hanya sebanyak 4,5 juta orang. Jumlah pembaca media cetak yang terus merosot karena masyarakat beranggapan bahwa ketersediaan informasi saat ini seharusnya bisa diperoleh secara gratis sebagaimana yang ditawarkan oleh media online. Survei tersebut juga menyebutkan media cetak kini hanya menjadi pilihan kelima masyarakat untuk mendapatkan informasi dengan penetrasi sebesar 8 persen (Suara.com. 25 Agustus 2021).

Pandangan lebih ekstrem dilontarkan Philip Meyer yang memprediksikan bahwa pada tahun 204300 keberadaan koran sudah punah, tidak lagi datang mengunjungi untuk memenuhi kebutuhan informasi pembacanya (Meyer, 2009). Sinyal kematian koran bahkan sudah terdengar ketika teknologi digital muncul dan melahirkan platform bernama social media. Secara perlahan para pembaca tidak lagi tergantung pada media cetak dalam mengakses berita (Hutomo, 2020; Pangaribuan \& Irwansyah, 2019).

Sejarah mencatat, sejumlah koran sudah mengakhiri masa baktinya karena terkena dampak perkembangan teknologi informasi. Sembilan bulan setelah kemunculan virus Corona di Indonesia, pada Desember 2020, koran Indopos menyerah. Media tersebut tidak tahan menghadapi disrupsi digital sehingga pamit kepada pembacanya. Sebulan kemudian, tepatnya Januari 2021, giliran koran Suara Pembaruan dan Koran Tempo yang mengucapkan selamat berpisah dari dunia cetak (Ritonga, 2021).

Sergapan media online terhadap media cetak dan elektronik juga terjadi di Singapura. Di negara kecil namun dinamis secara ekonomi tersebut media online dan platform social media telah menjadi sumber yang paling sering digunakan untuk mendapatkan informasi (berita), jauh di depan televisi dan surat kabar.

Perubahan pola konsumsi informasi tersebut juga disertai penurunan pendapatan pada banyak perusahaan media Singapura. Misal, Singapore Press Hold ings, yang menerbitkan sebagian besar surat kabar di Singapura, termasuk surat kabar The Straits Times, telah memberhentikan 130 karyawan pada bulan Oktober 2017 (Tandoc, 2018). Di Filipina, Inquirer Holdings Incorp, yang memiliki The Philippine Daily Inquirer, juga mengalami penurunan pendapatan dari P39 juta pada tahun 2010 menjadi P24 juta pada tahun 2013 (Tomacruz, 2017). 


\section{PROPAGANDA}

Di sisi lain, kehadiran media online berhasil mengubah panorama jurnalisme dunia. Perubahan yang terjadi tidak hanya menyangkut bergesernya pilihan masyarakat dari media konvensional ke media baru sebagai media arus utama untuk mendapatkan informasi. Lebih dari itu, perubahan yang terjadi juga menyangkut proses pemilihan isu yang hendak diberitakan, proses pengumpulan berita, proses pembuatan berita, dan proses penyebaran berita. Kerugian timbul ketika pemberitaan yang muncul dari pelbagai outlet media sering tampil secara bias, mengesampingkan isu-isu penting untuk publik, namun lebih mengedepankan kepentingan para pemilik media melalui isu-isu kontroversial. Belum lagi isi media makin menghindar dari risiko penggunaan jurnalisme berkualitas (quality journalism) hingga mengurangi upaya kerja jurnalis dalam melakukan investigasi terhadap suatu fakta sebelum diberitakan secara meluas (Abadi, 2019).

Bisa dikatakan jurnalisme saat ini memasuki suatu masa yang disebut masa disrupsi yaitu masa ketika perubahan terjadi sedemikian tidak terduga, bersifat mendasar dan hampir menyentuh semua sendi kehidupan masyarakat. Dunia hari ini sedang menghadapi fenomena di mana pergerakan dunia tidak lagi berjalan linear. Tatanan baru menggantikan tatanan lama yang dianggap sudah tidak sesuai dengan tuntutan zaman. Disrupsi menginisiasi lahirnya model interaksi baru yang lebih inovatif dan masif. Cakupan perubahannya luas. mulai dari dunia usaha, perbankan, transportasi, sosial, kemasyarakatan, pendidikan, politik hingga ke aspek media (pers). Era disrupsi melahirkan dua pilihan penting yaitu berubah atau punah (Khoiruddin, 2018).

Ini yang sementara terjadi pada jurnalisme konvensional yang mulai ditinggalkan pembaca serta pemasang iklannya dan kemudian beramai-ramai beralih ke jurnalisme online yang dianggap lebih cepat, interaktif dan masif. Dihadapkan dengan ketidakpastian jurnalisme di era disrupsi seperti saat ini, seorang mantan pemimpin redaksi sebuah organisasi berita terkemuka di Amerika Serikat yang mengajukan kebangkrutannya pada tahun 2009 lalu mengatakan, dirinya tidak punya pilihan selain "berubah" atau "mati". (Tandoc, 2019).

Kecanggihan media online menjadi salah satu poin yang secara langsung memberikan kemudahan bagi para pekerja jurnalis, penyedia konten, sampai masyarakat pun bisa ikut serta menyebarkan berbagai macam berita dari berbagai sudut pandang yang menghasilkan sebuah informasi di jejaring sosial. Saat ini media sosial seperti Youtube, Twitter, Facebook, Path Whatsapp, Line hingga Tiktok menjadi ajang citizen journalist untuk menjadikan media-media tersebut sebagai wadah bahkan pangkal dari sebuah informasi yang didapat dengan cara sangat mudah. Bahkan tidak sedikit citizen journalist lebih cepat menyampaikan berita melalui media sosial dibanding jurnalis media cetak atau elektronik. Sebagian mereka menguasai teknik penulisan, fotografi, videografi dan video editing. D imana keterampilan tersebut belum tentu dimiliki oleh jurnalis media cetak.

Di sisi lain, ini berdampak pada jurnalis media online yang dituntut untuk menguasai pembuatan berita dengan multiplatform. Maksudnya di sini, jurnalis online selain memiliki keterampilan menulis yang mumpuni juga dituntut dapat menguasai perangkat media online, seperti Adobe Flash, video editing, dan lain-lain yang diaplikasikan ke dalam berbagai platform berita, baik pada portal induk maupun social media. Idealnya jurnalisme multiplatfrom dapat menunjukkan sejauh mana kreativitas para pekerja media online mampu mengoptimalkan jurnalisme yang sesungguhnya yaitu dituntut untuk lebih terampil dalam penyediaan konten baik visual maupun penulisan, juga dituntut untuk lebih cepat dan kreatif dalam berinovasi penampilan berita dan informasi (Muliawanti, 2018).

Di balik semua itu, permasalahan yang sering ditemui dari jurnalisme online adalah masalah makin berkurangnya upaya penegakan prinsip-prinsip jurnalistik seperti objektivitas, verifikasi (check, recheck, cross check) dan cover both sides. Ini yang sering kali diabaikan hingga tidak ditegakkannya etika jurnalistik dalam pemberitaan. Artinya kualitas jurnalis media online masih bermasalah, padahal untuk menjadi jurnalis online, seseorang dituntut 
untuk memiliki jiwa kreatif, terampil, serta intelektualitas yang tinggi dibandingkan dengan jurnalis media konvensional. Karena sebuah informasi dan berita tidaklah serta merta hanya untuk disebarkan melainkan harus ada pertanggung jawabannya pasca dibaca maupun didengar oleh masyarakat.

Contoh betapa lemahnya penegakan prinsip- prinsip jurnalistik dalam jurnalisme online adalah berita tentang penyerahan donasi sebesar Rp 2 triliun dari keluarga Akidi Tio. Ia seorang pengusaha Tionghoa warga Palembang yang memberikan wasiat kepada anak-anaknya sebelum mengembuskan nafas terakhir. Anak Akidi Tio yang merupakan perwakilan dari ahli waris secara simbolis menyerahkan donasi ini untuk penanganan Covid-19 di Sumatera Selatan kepada Kapolda Sumatera Selatan, Irjen Pol Eko Indra Heri, pada tanggal 26 Juli 2021. Penyerahan donasi tersebut turut disaksikan Gubernur Sumatera Selatan Herman Deru, tokoh agama dan tentu saja pihak media (Suarasumsel.id, 26 Juli 2021).

Ironisnya, pada hari itu, hampir semua media menempatkan berita donasi Akidi Tio sebagai berita utama karena memiliki news value yang tinggi dari sisi jumlah donasi yang disumbangkan. Bahkan sosok Akidi Tio dianggap sebagai salah satu pemberi donasi perseorangan terbanyak untuk penanganan Covid-19 di Indonesia setelah Datuk Tahir (pimpinan grup Mayapada) dan pemberi donasi terbesar kedua di dunia setelah Bill Gates (Liputan6.com, 29 Juli 2021). Berdasarkan pengamatan penulis di sejumlah portal berita terkemuka, tampaknya tak ada satu pun portal berita yang pada hari itu (26 Juli 2021) melakukan verifikasi secepatnya pasca publikasi terkait sosok Akidi Tio dan kebenaran besarnya donasi yang mencengangkan publik. Padahal media berita online mampu melakukan itu mengingat kemampuannya yang memungkinkan untuk melakukan update informasi dalam hitungan jam atau menit dan kemudian menyiarkannya kembali secara cepat.

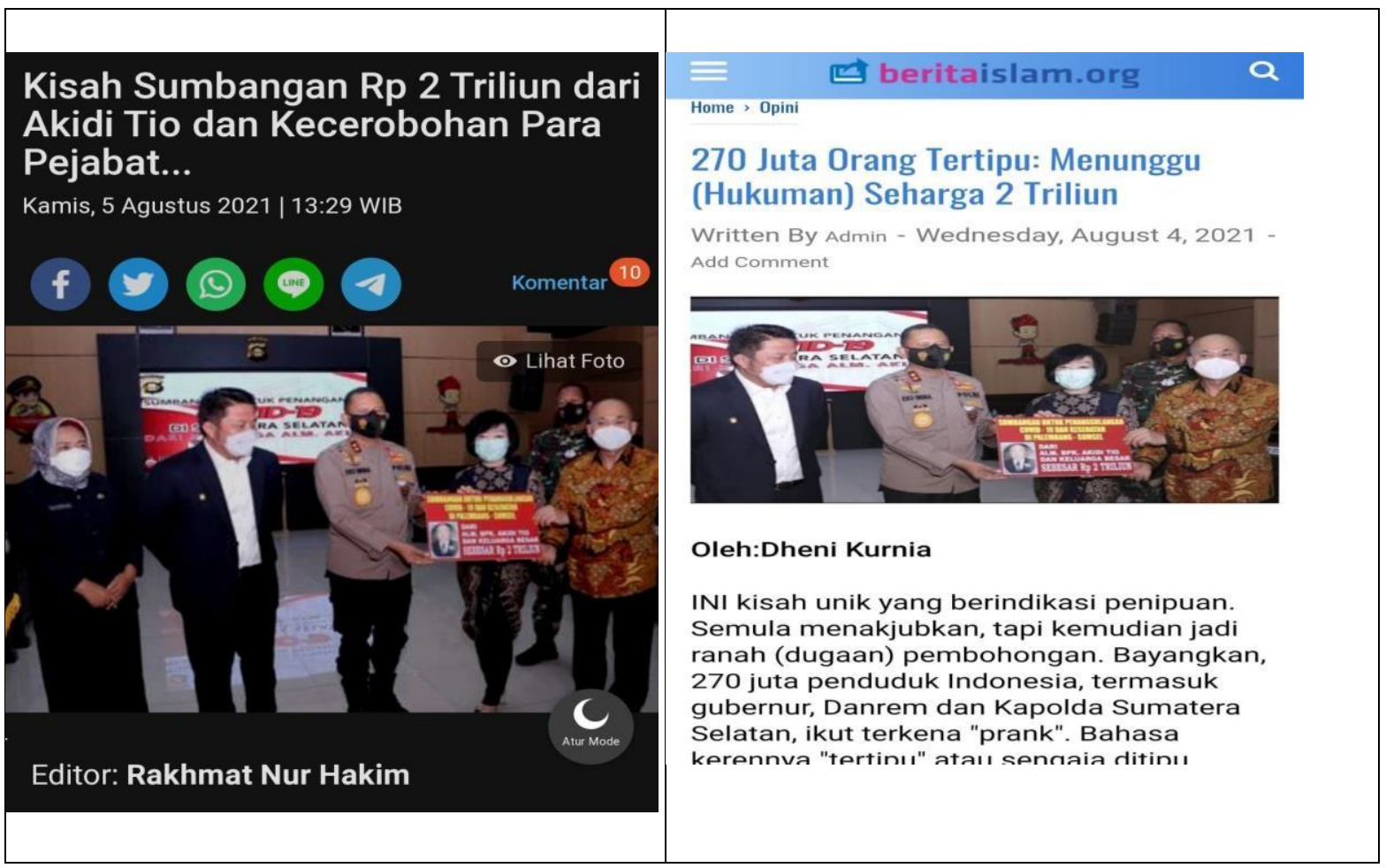

Gambar 1. Pihak media menyalahkan para pejabat terkait kasus donasi Akidi Tio

Ketika sejumlah pihak menanyakan kelanjutan dari donasi Akidi Tio yang belum bisa dilihat wujudnya seminggu kemudian, terungkap bahwa bilyet giro anak Akidi Tio yang fotonya ramai beredar di social media sesungguhnya tidak bisa dicairkan karena dana yang tersimpan tidak mencukupi angka yang tertera di bilyet giro tersebut. Fakta ini kemudian 


\section{PROPAGANDA}

kembali di blow up oleh media online tanpa mengedepankan prinsip cover both side (adil dan berimbang). Misalnya, tak ada satu pun kutipan wawancara langsung dari pihak keluarga Akidi Tio. Kutipan wawancara cenderung didominasi oleh sumber-sumber berita yang dianggap relevan (dari kacamata media) untuk memberikan pernyataan. Dan ini terus bergulir hingga hari ini. Bahkan beberapa media berita online balik menyudutkan pihak kepolisian dan juga pejabat daerah yang hadir dalam serah terima donasi tersebut dalam pemberitaan mereka. Padahal media berita juga merupakan bagian dari pihak yang harusnya turut dipersalahkan, karena sedari awal tidak mengedepankan prinsip-prinsip jurnalistik dalam memberitakan Akidi Tio. Idealnya, media harus melakukan verifikasi prapublikasi, bukan sebaliknya. Ini dapat dimaknai bahwa suatu realitas sengaja dikonstruksi oleh media hanya untuk memancing perhatian dan diskusi publik semata dan ini tak lain terkait kepentingan ekonomi politik pemilik media tanpa mempertimbangkan kualitas berita atau informasi yang disebarluaskan.

Selain berita Akidi Tio, realitas lain yang sengaja dikonstruksi untuk memancing perhatian dan diskusi publik adalah blusukan Presiden Jokowi di kawasan Bogor pada 23 Juli 2021 lalu. Ini terkait langkanya stok sejumlah obat yang biasa digunakan masyarakat untuk mengobati Covid-19 di sejumlah apotek di kawasan Bogor. Jokowi pun mendatangi salah satu apotek untuk mengecek ketersediaan obat anti virus Covid-19 yakni Oseltamivir dan Favipiravir. Begitu pula ketika Jokowi menanyakan ketersediaan obat antibiotik Acetromicin dan vitamin D3 5000UI. Namun obat-obatan itu kebetulan kosong saat Jokowi mendatangi salah satu apotek. Dalam blusukannya tersebut, Presiden Jokowi memperlihatkan dirinya langsung menelepon Menteri Kesehatan Budi Gunadi dan meminta agar masalah ini segera ditindaklanjuti (Urbanasia.com, 23 Juli 2021). Sebelumnya, Jokowi pernah melakukan blusukan di kawasan Sunter, Jakarta Utara, pada 16 Juli 2021. Jokowi fokus membagi- bagikan paket sembako, obatan-obatan dan vitamin kepada masyarakat Jakarta Utara (Urbanasia.com, 16 Juli 2021).

Media pun ramai-ramai memblow-up blusukan Presiden Jokowi, namun tidak menyertakan sejumlah fakta lain yang ada di lapangan terkait sejauh mana ketersediaan obat dan vitamin yang sangat dibutuhkan masyarakat agar bisa sembuh dari Covid-19. Selain itu, tak ada satu media berita online yang mempertanyakan blusukan Presiden Jokowi yang tanpa didampingi menteri atau pejabat terkait, sehingga bila dikritisi dari perspektif politik maka berita tersebut sangat menguntungkan pihak Jokowi dan tidak menguntungkan pihak yang lain, seperti menteri kesehatan, kepala BPOM dan pejabat terkait lainnya. Entah mengapa saat ini sulit menemukan media berita online yang menggunakan teknik investigasi sebagai upaya check, recheck dan crosscheck terkait berita blusukan Presiden Jokowi.

Dua contoh berita tersebut memperlihatkan bagaimana media hanya mengejar keuntungan ekonomi dan kepentingan politik media semata, sehingga konten berita cenderung mengabaikan hal-hal ideal yang seharusnya dipenuhi dalam penulisan berita sebagaimana yang biasa ditemui di media berita konvensional, seperti memenuhi unsur $5 \mathrm{~W}+1 \mathrm{H}$, menegakkan prinsip dan elemen jurnalistik hingga etika jurnalistik. Bahkan terjadi apa yang disebut sebagai marginalisasi terhadap tema-tema nonkomersial seperti konten edukasi, informasi yang berkualitas, penjaga demokrasi hingga transformasi nilai-nilai luhur (kebaikan). Belum lagi penggunaan internet memberi kemudahan dalam hal memproduksi konten baik dari segi biaya maupun kapabilitas (Fuchs dan Sandoval, 2015). Bahkan internet pula yang memungkinkan khalayaknya dapat memproduksi konten berita sendiri (citizen journalism) dan mendistribusikannya secara luas (Gehl, 2015). Inilah yang terjadi hingga saat ini, di mana media dikendalikan oleh ideologi kapitalis (Apuke, 2017).

Dalam sistem media kapitalis, posisi publik hanya ditempatkan sebagai objek dari transaksi bisnis media. Hubungan publik dan media hanya sebatas antara produsen dengan konsumennya, tidak lebih dari itu. Dalam transaksi bisnis media, konsumen dengan populasi terbesar tentunya lebih mendapat perhatian serta layanan yang terbaik. Media hanya berfokus 
pada selera konsumen terbesar yang mungkin saja tidak mewakili kepentingan publik, sedangkan selera konsumen minoritas cenderung diabaikan walaupun itu mewakili kepentingan publik (Syahputra, 2013). Raymond Williams menilai, kemunculan ekonomi informasi di mana informasi, komunikasi, dan khalayak dijual sebagai komoditas (dalam Fuchs dan Sandoval, 2015). Karena informasi merupakan aspek penting dari produksi ekonomi dalam masyarakat informasi (Fuchs dan Sandoval, 2015). Di mana dalam masyarakat informasi seperti saat ini tak ada satu pun yang tidak membutuhkan informasi.

\section{New Media}

Perkembangan media di tengah masyarakat begitu cepat yang ditandai dengan munculnya media baru. Istilah media baru (new media) telah digunakan sejak tahun 1960-an dan telah mencakup seperangkat teknologi komunikasi terapan yang semakin berkembang dan beragam. Denis McQuail menyebut beberapa ciri utama media baru adalah adanya saling keterhubungan, aksesnya terhadap khalayak individu sebagai produsen maupun konsumen pesan, terdapat kegunaan yang beragam sebagai karakter yang terbuka, memiliki interaktivitas, dan sifatnya yang bisa berada di mana-mana (McQuail, 2000).

Bukan itu saja, sajian informasi di media online tidak perlu dibatasi ruang (halaman) seperti di media cetak dan tidak dibatasi oleh waktu (durasi) seperti yang dialami radio dan televisi. Dan media online memungkinkan semua komponen seperti teks (naskah), audio, video, foto, grafis, dan lain sebagainya. Semua komponen tersebut bisa tampil berbarengan jika menggunakan media online. Tak seperti radio dan televisi yang memaksa pemirsa untuk memasang mata dan telinga supaya tak ada informasi yang terlewatkan, pengguna media online memungkinkan untuk mengakses informasi tanpa merasa tersiksa karena harus berkonsentrasi. Audiens bisa mengomentari subyek berita sesuka hati mereka. Maksudnya di sini, audiens dimungkinkan untuk mengoreksi, memuji atau bahkan mengecam isi berita berikut dengan pembuat beritanya/kolumnis dan bahkan terhadap sesama pengakses berita online (Romli, 2018). Hal ini yang tidak mungkin dapat dilakukan oleh pengguna media konvensional.

Baran dan Davis (2010) menjelaskan bahwa media baru hadir dan menawarkan suatu "perilaku komunikasi dalam skala yang besar" untuk dipelajari. Pertama, interconnectivity; dalam media baru "secara signifikan menguatkan inti pemahaman (uses and gratifications) dari pengguna media aktif. Hal ini karena keterhubungan dalam komunikasi massa telah lama dianggap sebagai derajat ketika partisipan dalam proses komunikasi memiliki kontrol, dan dapat mengubah peran dalam wacana mereka secara timbal balik (William, Rice dan Rogers, 1988 dalam Baran dan Davis, 2010). Kedua, demassification yaitu kemampuan pengguna media baru untuk memilih dari banyaknya fitur-fitur yang ditawarkan. Ini karena media baru menyediakan karakteristik selektif yang memungkinkan individu untuk merangkai pesan ke dalam kebutuhan mereka. Dan ketiga yaitu asynchroneity, di mana pesan termediasi sehingga pengirim maupun penerima pesan dapat saling berkirim pesan pada waktu yang berbeda, tapi masih memungkinan untuk berinteraksi secara leluasa dan nyaman. Artinya, setiap individu bisa mengirim, menerima, menyimpan, dan mendapatkan pesan pada saat atau kondisi yang ia inginkan. Merujuk apa yang dikatakan Ruggiero, sekali pesan terdigitalisasi, maka manipulasi media menjadi tidak dapat diukur, membuat seseorang memiliki lebih banyak kontrol daripada pengguna media konvensional (Baran dan Davis, 2010).

\section{Jurnalisme Online}

Jurnalisme adalah aktivitas mencari informasi akurat mengenai sebuah peristiwa, di mana informasi yang didapatkan itu dikemas untuk kemudian disebarluaskan kepada publik (Shapiro, 2013). Canggihnya teknologi informasi komunikasi mendorong para jurnalis online untuk dapat menunjukkan kreativitas mereka dalam hal memaksimalkan jurnalisme yang sesungguhnya. Hal tersebut juga didukung dengan lahirnya jurnalisme digital atau jurnalisme 


\section{PROPAGANDA}

online yang telah menyasar ke dunia jurnalistik di era digitalisasi media seperti sekarang. Secara tidak sadar pun jurnalisme online akan melakukan berbagai macam cara agar dapat memberikan berita atau informasi yang terbaik dalam bentuk tulisan maupun audio visual. Tak hanya itu, mereka juga dituntut untuk lebih cepat dan kreatif dalam berinovasi dalam menampilkan berita maupun informasi yang hendak disajikan.

Foust mencatat beberapa potensi atau kekuatan jurnalisme online sebagai sumber informasi utama bagi masyarakat. Kekuatan yang dimaksud antara lain: pertama, informasi dapat disampaikan secara cepat dan langsung kepada masyarakat (immediacy); kedua, setiap berita yang disampaikan dapat berdiri sendiri (nonlienarity); ketiga, berita mudah tersimpan dan bisa diakses kembali kapan saja dengan mudah oleh masyarakat (storage and retrieval); keempat, jumlah berita yang disampaikan bisa lebih banyak dan menjadi jauh lebih lengkap (unlimited space); kelima, audiens bisa lebih leluasa dalam memilih tema berita yang dibutuhkan (audience control); keenam, redaksi bisa menyertakan teks, suara, foto, gambar, animasi, video, maupun komponen lainnya ke dalam berita yang akan diterima oleh masyarakat (multimedia capability); dan ketujuh, memungkinkan adanya interaksi antara pembuat konten dengan audiens (interactivity) (Foust, 2018).

\section{METODE}

Pendekatan penelitian dalam tulisan ini adalah pendekatan kualitatif. Menurut Rachmat Kriyantono (2010), riset kualitatif bertujuan untuk menjelaskan fenomena dengan sedalamdalamnya tanpa mengutamakan besarnya populasi atau sampling. Salah satu cirinya adalah subyektif dan hanya berada dalam referensi periset. Periset sebagai sarana penggalian interpretasi data.

Adapun metode dalam tulisan ini didasarkan pada metodologi kajian kepustakaan (library research) dengan menggunakan analisis deskriptif. Metode ini menyajikan beragam fakta dan data dalam sejumlah literatur, baik yang sifatnya primer maupun sekunder. Untuk mengoptimalkan pendekatan yang digunakan untuk menganalisis fenomena jurnalisme Indonesia di masa disrupsi tentunya didasarkan pada berbagai kerangka teoritis dan konsep. Diantaranya dengan pendekatan beberapa teori dan konsep jurnalistik, dinamika perkembangan teknologi dikaitkan konten berita, dinamika perkembangan media, serta sejumlah pendekatan dampak dari digitalisasi media ini di masyarakat.

\section{HASIL DAN PEMBAHASAN}

\section{Kehadiran Jurnalisme Online}

Cara mendapatkan berita saat ini sudah jauh berbeda sebelum hadirnya media online. Ketika itu orang mengandalkan koran terbitan pagi atau koran terbitan sore untuk mendapatkan informasi terkini atau cukup dengan menyetel saluran berita televisi dan radio untuk mengetahui peristiwa yang terjadi di seluruh belahan dunia. Namun di era digital saat ini, semakin banyak pembaca, pendengar dan pemirsa yang memilih media online untuk mencari berita yang mereka butuhkan, karena lebih mudah, cepat dan bisa di akses kapan pun dan di manapun serta apapun berita telah tersedia dari berbagai sudut pandang. Televisi, surat kabar dan radio memang masih ada, namun terdapat kompetisi yang sangat ketat karena kehadiran media online.

Secara tidak sadar, pemberitaan telah berevolusi pasca hadirnya jurnalisme online, dimana berita bukanlah lagi peristiwa yang 'sudah berlanngsung' tetapi menjadi peristiwa yang 'sedang berlangsung' hal ini sejalan dengan istilah 'kecepatan' yang secara garis besar 
menggambarkan hadirnya jurnalisme online. Hanya dalam hitungan menit bahkan detik segala berita yang disiarkan melalui internet akan selalu banyak menyajikan berita yang memungkinkan pengguna untuk meng-update berita dan informasi. Karena itu, masyarakat melihat internet sebagai media yang 'cepat' dari pada media yang 'lebih detil' dalam menyajikan informasi.

Tentunya ini menuntut jurnalis untuk serba cepat dalam menyebarkan berita. Namun ini juga yang kemudian memunculkan berbagai pertanyaan mengenai profesionalitas jurnalis itu sendiri. Dan ini sering kali dipertanyakan di mana jurnalisme online menjadi sesuatu yang kompleks karena di samping perkembangannya yang begitu pesat, perkembangan tersebut tidak diimbangi dengan hadirnya standar dan aturan yang mengatur. Misalnya, terdapat kriteria yang mengatur di mana suatu informasi disebut akurat menurut standar jurnalistik. Mengutip kriteria McQuaill (2005) yang menyampaikan ada tiga sudut pandang mengenai informasi yang akurat, yakni (1) sesuai dengan fakta peristiwa; (2) sesuai dengan persepsi atau apa yang dibicarakan narasumber sebuah peristiwa dan (3) adanya konsistensi dalam paparan informasi di sebuah teks berita.

Salah satu kaitannya pendapat dari Mc Qual ini dengan pemberitaan tentang keberadaan donasi Rp 2 Triliun Akidi Tio yang masih misterius itu, maka apa yang diberitakan media konvensional maupun media online belum sesuai dengan fakta peristiwa. Apalagi memasuki era di mana banyak sekali beredar fakta alternatif melalui media online, jurnalis justru harus tetap berpegang erat pada penegakan prinsip-prinsip jurnalistik antara lain yakni ketat dan disiplin dalam melakukan verifikasi serta pengecekan fakta di lapangan. Melalui cara kerja pengecekan fakta ini misalnya, pernyataan atau sisi dari sebuah peristiwa yang dianggap meragukan dapat dengan cepat dicek kebenarannya oleh jurnalis melalui verifikasi. Apakah donasi sebesar Rp 2 Triliun tersebut memang benar ada wujudnya? Jika benar, mengapa baru sekarang tergerak untuk memberikan donasi sebanyak itu? Di mana uang sebanyak itu berada? Dan masih banyak lagi pertanyaan-pertanyaan yang sifatnya skeptis yang harusnya muncul di awal liputan. Bukan malah ikut-ikutan percaya sepenuhnya dengan angka yang tertulis di bilyet giro yang diberikan oleh keluarga Akidi Tio untuk diperlihatkan kepada publik. Selain itu, tak ada satu pun media yang melakukan klarifikasi di awal kepada sumber-sumber terpercaya terkait keberadaan Rp 2 Triliun ini. Harusnya setelah dipastikan fakta itu benar atau palsu, jurnalis sebagai penginformasi fakta dapat menuliskan naskah berita dan kemudian menyebarluaskan ke publik. Adapun pernyataan yang mencurigakan itu disimpan sebagai 'fakta berat' ' berikutnya, yang suatu saat bisa dijadikan bahan investigasi untuk pemberitaan selanjutnya. Dengan demikian, berita yang layak disebarluaskan tersebut merupakan informasi yang akurat.

Secara tidak langsung antara media kovensional dengan media online memiliki hubungan simbiosis mutualisme. Di mana tren media berita online tampaknya bisa menggerus keberadaan media berita konvensional, pun media berita konvensional tidak jarang terbawa gaya media berita online dalam menyajikan kontennya. Di sisi lain, media massa mainstream ikut mengamplifikasi apa yang terjadi di media online, khususnya platform social media. Dan sebaliknya, media online kadang-kadang mengamplifikasi kekeliruan maupun kesalahan yang ada di media massa mainstream.

Bisa dikatakan saat ini pers Indonesia berada di persimpangan jalan yang cukup rawan di masa disrupsi informasi. Di mana masa depan jurnalisme dan makna kebebasan menjadi taruhannya. Apakah jurnalis harus menyerah? Di sinilah pentingnya produk jurnalistik media konvensional, yang membawa marwah elemen- elemen jurnalisme, agar tetap bisa dihadirkan di tengah masyarakat. Pelebaran sayap media massa baik cetak maupun elektronik dengan membuat versi media online sudah menjadi suatu keharusan. Media konvensional harus mampu beradaptasi dengan digitalisasi. Perusahaan media yang beradaptasi ditunjukkan dengan menerapkan serangkaian strategi merger dan akuisisi. Strategi-strategi itu dilakukan 


\section{PROPAGANDA}

dengan mengarahkan bisnis media ke arah online dan konvergensi (Tapsell, 2017).

Perubahan yang terjadi dalam bisnis media, tetap harus kita sangka baik. Karena ini sebenarnya adalah salah satu bentuk strategi yang dilakukan media massa mainstream untuk mengimbangi cepatnya informasi yang beredar melalui platform di media online. Meski sebagian masyarakat ada yang beranggapan bahwa ini tak lain adalah bentuk "pelebaran sayap" media massa mainstream yang bisa dikategorikan sebagai praktik monopoli media bahkan bagian dari konglomerasi media. Tentu saja ini merupakan konsekuensi yang harus diterima. Namun ada satu hal yang tidak bisa diabaikan bahwa perolehan iklan merupakan salah satu ruh utama dari kehidupan media massa. Dengan merambah dunia internet yang cakupannya mendunia, dan bisa dikses siapapun maka iklan akan lebih mudah masuk dan dinikmati banyak orang, hingga akhirnya bisa menghasilkan profit bagi media bersangkutan.

Selanjutnya, hal lain yang masih menjadi salah satu masalah besar dalam jurnalisme online adalah post terkait isu-isu kontroversial sampai informasi hoax tanpa adanya check, recheck dan crosschek. Belum lagi pemberitaan headline berita yang bombastis dan sensasional namun seringkali tidak relevan dengan isi berita. Ini juga menjadi masalah yang kerap disebut sebagai degradasi terhadap kualitas jurnalisme konvensional maupun jurnalisme online. Namun demikian, tidak semua media konvensional dan juga media berita online mengalami degradasi tersebut. Berdasarkan pengamatan penulis pada beberapa media berita online misalnya, beberapa media masih ada yang menerapkan standar penulisan berita yang patuh pada prinsip-prinsip jurnalistik dan etika jurnalistik, seperti Tirto.id dan Kumparan.com. Walaupun media seperti ini juga menghadapi masalahnya sendiri di mana banyak audiens yang lebih tertarik terhadap media yang mengusung headline yang bombastis atau sensasional.

Seperti dua contoh berita berikut ini :

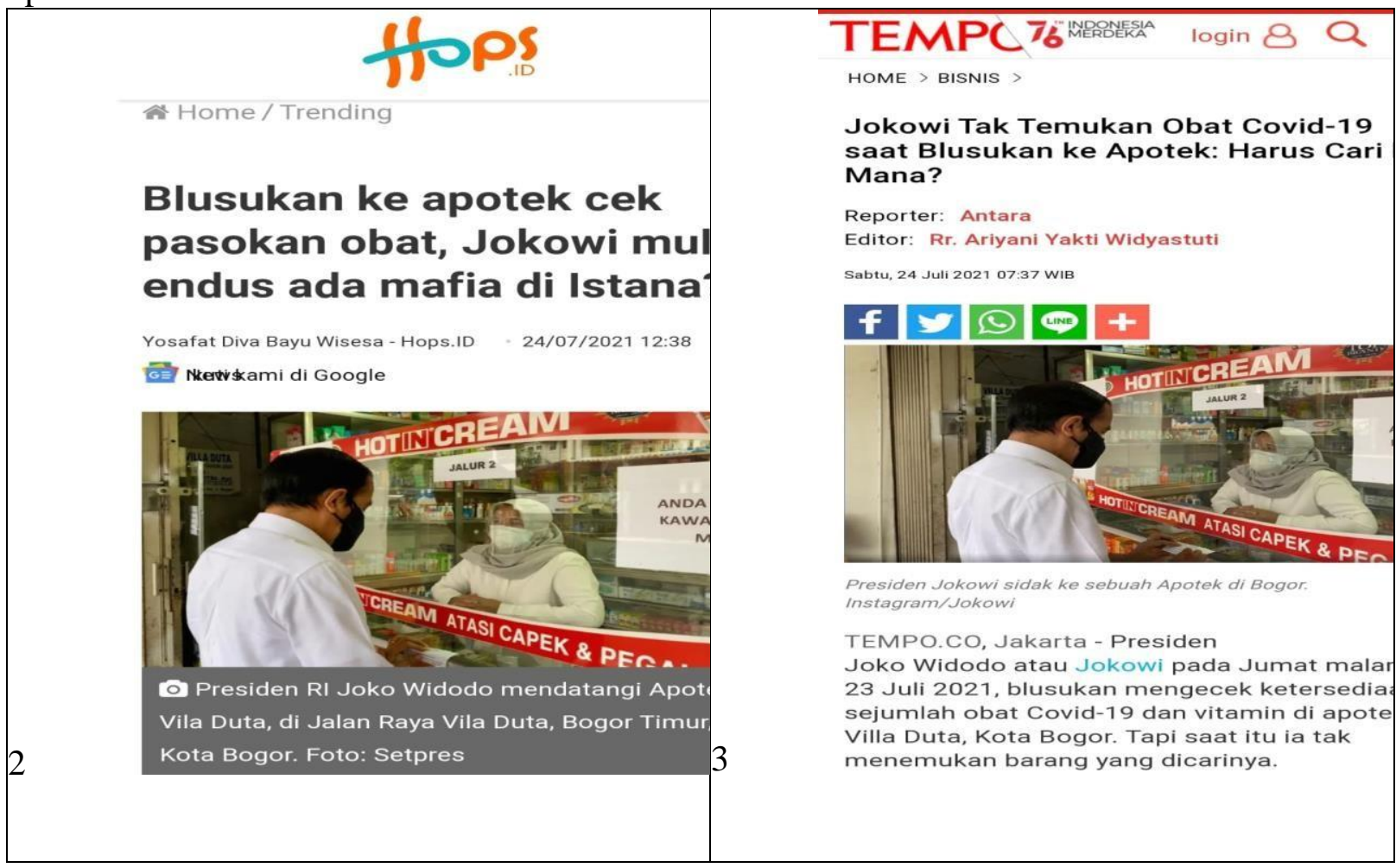

Gambar 2. Headline bombastis pada jurnalisme digital

\section{Jurnalisme Online di Masa Disrupsi}

Teknologi digital membawa disrupsi terhadap jurnalisme yang terjadi dalam tiga hal yaitu pertama, perubahan karakter persaingan bisnis media saat ini; kedua, terjadinya penyempitan finansial untuk biaya produksi berita, dan ketiga, perubahan norma-norma serta cara kerja wartawan dalam melakukan peliputan. Ketiga disrupsi digital inilah yang pada 
gilirannya berdampak terhadap konten berita yang diliput dan disusun oleh jurnalis hingga berita tersebut sampai kepada publik.

Perubahan karakter persaingan bisnis media misalnya, menunjukkan bagaimana sebagian besar portal berita online cenderung mengedepankan logika bisnis untuk memperluas pangsa pasar, berusaha sedemikian rupa mempertahankan eksistensi media selaku industri bisnis yang menguntungkan, meraup keuntungan melalui produk jurnalisme yang mengedepankan isu-isu kontroversial serta penggunaan judul-judul yang bombastis dan sensasional bahkan sampai berita hoax pun tidak luput dari kurangnya pendalaman akan informasi terkait demi mengejar 'kecepatan' yang menjadi faktor utama dari sebuah berita. Situasi demikian membuat jurnalisme online kerap lebih cenderung bergerak berdasarkan minat pasar (market interest oriented) dibandingkan kepentingan publik (public interest oriented) yang membutuhkan informasi benar dan akurat.

Salah satu keuntungan media online yang tidak bisa diperoleh oleh media konvensional adalah dari jumlah traffic yang merupakan sebuah nilai tukar untuk menarik para pengiklan. Traffic adalah aktivitas pada satu halaman situs yang dihasilkan dari kunjungan pengguna internet dan lamanya aktivitas pengguna internet di halaman itu (Margianto \& Syaefullah, 2014). Bahkan ironisnya, dengan kecenderungan ini dan juga karena tuntutan bisnis, media online ramai-ramai latah mengikuti arus dengan membuat berita-berita berjudul bombastis. Fenomena ini terkenal dengan nama "clickbait".

Fenomena clickbait mencuat dalam dunia media online, tujuannya hanya satu yaitu menarik pembaca berita online sebanyak-banyaknya untuk masuk ke sebuah situs web dan mendulang apa yang disebut sebagai page view atau jumlah click yang masuk. Mark Bulik, editor senior The New York Times mengatakan bahwa ada perubahan strategi dalam hal pembuatan judul dalam memasuki era digital. Namun Mark mengingatkan, agar judul yang muncul tidak membuat pembaca merasa tertipu saat membaca dan menuntaskan sebuah artikel. Sebab ukuran clickbait adalah saat pembaca merasa tertipu. Clickbait merupakan manipulasi. Abhijnan Chakraborty, dari Indian Institute of Technology Kharagpur, dalam papernya berjudul "Stop Clickbait: Detecting and Preventing Clickbaits in Online News Media" mengungkapkan bahwa clickbait mengeksploitasi sisi kognitif manusia yang disebut curiosity gap. Ini karena judul clickbait memantik konsekuensi emosional, pembaca yang mengklik artikel merupakan pembaca yang sesungguhnya hanya ingin memuaskan sisi emosionalnya saja, bukan pembaca yang benar-benar membutuhkan informasi yang berkualitas.

Menariknya lagi, meskipun clickbait dianggap bagian dari manipulasi atau jebakan, korbannya (pembaca) justru mereka sadar bahwa mereka telah tertipu (Abadi, 2019). Namun saat ini, dengan adanya fenomena clibkbait tersebut memunculkan beberapa aplikasi untuk membantu warganet (pembaca) untuk mendeteki adanya informasi atau berita yang punya kecenderungan clickbait. Kecenderungan yang dilakukan media itu sangat mudah dipahami, mengingat masyarakat mudah sekali terpapar informasi awal yang menarik meskipun kebenarannya masih diragukan, layaknya arus berita hoax yang gencar sampai hanya melihat dari headline saja tanpa membaca detail isinya.

\section{Jurnalisme Online: Idealisme dan Kredibilitas Jurnalis}

Dampak teknologi internet menyebabkan media berita online mengalami revolusi radikal yang membuatnya berbeda dengan jurnalisme di media massa pada umumnya. Beberapa fitur dalam jurnalisme online justru disebut sebagai ragam penyebab dari terjadinya pengikisan idealisme dan kredibilitas dalam jurnalisme online.

Dalam media cetak dan elektronik, suatu berita ditulis dan disebarluaskan berada dalam rangkaian sistem kerja media (Shoemaker dan Reese, 1996) di mana standar profesional menuntut berita harus disusun dengan mengutamakan akurasi dan keberimbangan (Mencher, 2000; McQuail, 1992; Rahayu, 2006; Rianto, 2007). Sementara para penyedia konten media 


\section{PROPAGANDA}

baru, dalam beberapa hal, tidak terikat pada sistem kerja yang berlaku di media konvensional. Ketika seseorang dapat berperan sebagai penerima pesan dan juga pemroduksi pesan dalam waktu yang hampir bersamaan, maka standar profesional dengan sendirinya menjadi turut 'lenyap'. Audiens bisa dengan mudahnya terjebak dalam informasi-informasi yang tidak menjunjung tinggi akurasi sebagaimana standar jurnalistik yang menjadi acuan di jurnalisme konvensional.

Serba cepat yang secara tidak langsung mengundang berbagai macam permasalahan, utamanya di era digital saat ini, di mana jurnalis online dituntut untuk menghadapi kemajuan teknologi. Mulai dari aspek konsep berita, pengumpulan data dan berita serta informasinya yang selalu mengutamakan kecepatan dan telah menggeser nilai-nilai jurnalisme konvensional. Salah satu pergeseran yang cukup mendasar adalah makin tipisnya batas antara media profesional dan social media. Jurnalisme bukan hanya memanfaatkan social media sebagai sarana penyebaran informasi tambahan, tapi juga sebagai sarana menggali informasi. Praktek seperti ini dinilai sebagai salah satu bentuk inovasi dalam jurnalisme, karena jurnalis tidak hanya terpaku pada teknik pengumpulan informasi lawas, namun mampu melakukan inovasi dalam pencarian berita sesuai perkembangan teknologi yang ada. Hal ini pula yang menjadi salah satu faktor positif yang dirasakan di zaman serba digital. Apalagi dalam menjalankan pekerjaannya, jurnalis online ditunjang dengan hadirnya teknologi internet yang memungkinkan pencarian data tanpa batas.

Akan tetapi karena faktor mengejar aktualitas sekaligus kecepatan, pemberitaan pada jurnalisme online sering kali berdasarkan isu yang sering tidak jelas sumbernya, tidak berdasarkan fakta yang terjamin keakuratannya, sampai ada pemberitaan yang seakan-akan dipaksakan untuk terbit tanpa adanya kebenaran yang detail. Bahkan tak jarang informasi tersebut merugikan beberapa pihak karena tidak jelas kebenarannya dan tidak cover both sides. Padahal, cover both sides ini penting agar masyarakat tidak menghakimi pihak-pihak tertentu yang dibicarakan dalam pemberitaan.

Kompetisi dalam hal kecepatan untuk mempublikasikan berita memang merupakan hal yang utama dalam jurnalisme online. Sementara peristiwa masih berkembang dan fakta kunci belum diketahui, kompetisi untuk menjadi yang pertama menerbitkan sebuah berita sering kali mendorong para jurnalis online untuk melalaikan peran mereka sebagai filter untuk membedakan berita dari rumor yang belum jelas. Mike Ward menyebutkan beberapa karakterisitik jurnalisme online sekaligus yang membedakannya dengan media konvensional salah satunya yaitu kesegeraan atau kecepatan (immediacy) dalam menyampaikan informasi (Muliawati, 2018).

Di sisi lain, kehadiran teknologi digital dalam konteks jurnalisme ternyata menjadi kesempatan yang disalahgunakan oleh jurnalis online di media mainstream maupun citizen journalism yang tidak bertanggung jawab. Tentu saja ini menambah persoalan dalam dunia jurnalisme online. Dengan kemudahan mengakses melalui jaringan data, menjadikan dunia jurnalisme online menjadi sasaran 'empuk' dalam plagiasi. Lihat saja isi berita hingga foto yang digunakan misalnya cenderung sama. Yang membedakan adalah pemilihan headline. Ada headline yang relevan dengan isi berita, namun tidak sedikit headline yang sama sekali tidak relevan dengan isi berita, begitu pun sebaliknya. Sebagaimana dijelaskan penulis sebelumnya bahwa tuntutan bisnis media mendorong pelaku jurnalisme menggunakan cara-cara yang melanggar pakem jurnalistik demi mengejar click pembaca berita dan hal ini pastinya memiliki kepentingan masing-masing di setiap tekniknya.

Mengapa kredibilitas jurnalisme konvensional masih dianggap lebih tinggi dibandingkan dengan jurnalisme online? Kredibilitas dan obyektivitas jurnalisme konvensional didukung dan dijamin oleh penyaring informasi (gate keeper). Data yang diperoleh di lapangan harus diolah dan difilter lebih dahulu sampai akhirnya keluar menjadi 'berita'. Editor pun melakukan kontrol yang ketat terhadap isi berita dan melakukan pemeriksaan terhadap fakta 
yang ditulis oleh wartawan, bukan dengan menyiarkan begitu saja tanpa adanya pertanggung jawaban di dalamnya. Sehingga kalangan jurnalisme konvensional beranggapan kredibilitas suatu pemberitaan sesungguhnya mewakili kredibilitas media di mana mereka bekerja. Apabila masyarakat sudah tidak percaya terhadap kebenaran informasi yang disampaikan oleh media, maka masyarakat tidak akan mengkonsumsi media itu lagi dan mereka segera beralih pada media yang terpercaya. Akibatnya, media lambat laun akan ditinggalkan khalayaknya dan terancam kekurangan pembaca karena adanya kesalahan fatal dalam menyampaikan data dan peristiwa.

Jurnalisme online memiliki kecenderungan lain. Karena faktor mengejar kecepatan dan aktualitas, pemberitaan pada jurnalisme online sering kali berdasarkan isu-isu yang sering tidak jelas sumbernya, tidak berdasarkan fakta. Tak jarang informasi tersebut merugikan beberapa pihak karena tidak jelas kebenarannya dan kurang cover both sides. Padahal pemberitaan yang mengutamakan cover both sides membuat media tetap dalam posisi yang adil dan berimbang. Media hanya bertugas menyampaikan informasi secara seobyektif mungkin, tanpa keperpihakan. Kalau pun harus berpihak, tentunya keberpihakan itu lebih pada unsur kebenaran. Media tidak boleh mencampurkan opini dan menjunjung tinggi asas praduga tak bersalah (Priyambodo, 2008). Untungnya jurnalisme online yang berbasis pada jurnalisme konvensional menjadikan masalah kredibilitas bukanlah suatu masalah karena sumber berita yang diperoleh masih dapat dipertanggungjawabkan.

Pengikisan idealisme dan kredibilitas jurnalis online bisa terjadi karena faktor persaingan yang ketat antar media dan tuntutan kecepatan untuk menghadirkan berita yang menyebabkan jurnalis online sering kali abai pada elemen-elemen jurnalistik. Mereka lebih mengutamakan jargon jurnalisme untuk menyajikan berita secara cepat, akurat dan lengkap (ini masih bisa diperdebatkan), sehingga menjadi bernilai penting. Upaya menyajikan berita secara cepat, akurat dan lengkap membuat antar media massa dan jurnalisnya saling bersaing dengan mereka yang bekerja di media berita online. Bisa dipastikan, kecepatan dan anonimitas yang dimiliki internet bisa menyebabkan jurnalis kehilangan etika jurnalistik karena masingmasing dari keduanya tidak luput dari perlombaan yang sengit di era digital saat ini. Dan karena alasan tersebut, kaidah-kaidah dan etika jurnalistik ditinggalkan demi sebuah informasi yang harus segera diberitakan. Hal ini merupakan salah satu sifat dari media online sekaligus strategi dari media konvensional agar tidak ditinggalkan . Sehingga akurasi atau ketepatan berita menjadi kurang diperhatikan, dan jurnalis menjadi sekedar 'tukang' dan menggeser fungsi etisnya sebagai pencari dan pengecek fakta serta kebenaran. Karena tuntutan kecepatan, jurnalis cenderung tidak berhati-hati. Jurnalisme pernyataan (journalism of assertion) dengan cara door stop lebih dipilih, dari pada mencari dan mengecek fakta secara mandiri. Sungguh sesuatu yang memprihatinkan dan patut untuk mendapatkan literasi. Ini didukung dengan belum adanya hukum yang jelas dalam jurnalisme online. Bahkan, di dalam UU No 40 Tahun 1999 tentang Pers, peraturan bagi jurnalisme online pun tidak ditemukan. Tentunya ini mengakibatkan apa yang disebut dengan kebebasan yang kebablasan dalam jurnalisme online. Dan bila ini dibiarkan maka pihak yang dirugikan adalah masyarakat.

Hal lain yang merupakan penyebab utama dalam permasalahan ini adalah soal penguasaan ilmu jurnalistik yang minim yang mengakibatkan ketidaktahuan mengenai penegakan prinsip-prinsip jurnalistik, pemahaman terhadap elemen-elemen jurnalistik hingga kode etika jurnalistik. Contoh sederhana, di dalam jurnalisme online, informasi dari satu orang pun bisa menjadi berita. Lain halnya dengan jurnalisme konvensional, satu sumber dianggap tidak memadai sebagai berita yang layak siar. Perlu dilakukan check and recheck dan mengusahakan agar berita yang disajikan telah memenuhi unsur keberimbangan untuk menghindari keberpihakan media. Jika ada pihak yang dirugikan, jurnalisme konvensional jauh lebih rentan untuk dituntut melalui pengadilan (Priyambodo, 2008). Keberimbangan yang 


\section{PROPAGANDA}

dimaksud ini bukan pada jumlah sumber berita yang diperoleh, melainkan lebih pada keberimbangan dari dua sisi dan banyak sisi.

Perlu diingat bahwa idealisme dan kredibilitas para pekerja media berita online dalam melakukan tugas jurnalistiknya sebaiknya selalu mengedepankan sepuluh elemen jurnalisme sebagaimana yang disampaikan Bill Kovach dan Tom Rosenstiel, (2004) dalam bukunya yang menjadi rujukan wartawan sedunia yang berjudul, The Elements of Journalism. Sepuluh elemen jurnalistik dimaksud meliputi:

1. Kewajiban pertama jurnalisme adalah pada kebenaran, yaitu kebenaran fungsional, bukan kebenaran filosofis.

2. Loyalitas utama jurnalisme adalah pada masyarakat, bukan pada perusahaan media, pembaca atau bahkan pengiklan.

3. Esensi jurnalisme adalah disiplin dalam melakukan verifikasi.

4. Jurnalisme harus menjaga independensi dari pihak yang diliputnya.

5. Jurnalisme harus memfungsikan dirinya sebagai pemantau independen terhadap kekuasaan, menyambung lidah masyarakat yang tertindas.

6. Jurnalisme harus menyediakan forum bagi kritik dan komentar publik.

7. Jurnalisme harus mengupayakan hal-hal penting yang sifatnya memikat dan relevan.

8. Jurnalisme harus menjaga agar beritanya komprehensif dan proporsional.

9. Jurnalisme harus berkewajiban untuk mengikuti suara hati nurani.

10. Hak dan kewajiban warga terhadap hal-hal yang berkaitan dengan berita.

Apabila sepuluh elemen Kovach dan Rosenstiel diterapkan dalam jurnalisme konvensional maupun online, maka idealisme media sebagai pemberi informasi, mendidik, menghibur dan juga alat kontrol sosial dapat terwujud. Bahkan hal tersebut akan mengantar masyarakat pada level kritis yang senantiasa akan mengontrol kekuasaan pemerintah. Dengan penambahan idealisme dan kredibilitas jurnalis maka eksistensi jurnalisme online menjadi lebih diakui lagi. Selanjutnya, jurnalisme online dan jurnalisme konvensional dapat bersamasama menjadi sarana kontrol sosial dan pendidikan masyarakat.

\section{PENUTUP}

Kualitas berita dalam jurnalisme online mengalami pengikisan kredibilitas usai digitalisasi media menyasar ke dunia jurnalistik hal tersebut pula yang menyebabkan implikasi yang besar terhadap perkembangan jurnalisme di Indonesia Disrupsi tersebut terjadi baik pada level makro maupun mikro. Mulai dari karakter persaingan bisnis, pembiayaan produksi berita hingga perubahan cara menulis berita di kalangan jurnalis online.

Dampak teknologi internet menyebabkan media berita online mengalami revolusi radikal yang membuatnya berbeda dengan jurnalisme di media massa pada umumnya. Bisa jadi, persoalan-persoalan yang muncul dikarenakan belum adanya model yang jelas menyangkut bagaimana bentuk jurnalisme online yang benar (excellence) atau quality journalism yang menyebabkan beberapa fitur dalam jurnalisme online bisa dikatakan sebagai ragam penyebab dari terjadinya pengikisan idealisme dan kredibilitas dalam jurnalisme online. dan beberapa standar yang masih sedikit sekali dibakukan. Tentunya ini merupakan sesuatu yang dianggap mengherankan karena di samping perkembangannya yang begitu pesat, luas dan cepat serta sejalan dengan perkembangan teknologi, keberadaan jurnalisme online belum diimbangi dengan hadirnya standar dan aturan khusus yang mengatur, karena jurnalisme online lebih fleksibel oleh siapa pun,

Selain itu, perubahan karakter persaingan bisnis media di era internet mengantarkan jurnalisme online pada dilema dan himpitan antara mengedepankan berita berdasarkan minat pasar (market interest) atau minat publik (public interest). Keduanya bisa saja dilakukan 
sepanjang jurnalisme online tetap berada dalam rangkaian sistem kerja media, di mana standar profesional menuntut berita harus disusun dengan mengutamakan akurasi dan keberimbangan. Sebagaimana kalangan jurnalisme konvensional beranggapan bahwa kredibilitas suatu pemberitaan sesungguhnya mewakili kredibilitas media bersangkutan. Pada gilirannya, hal itu dapat berdampak pada kualitas konten berita yang diproduksi media. Hal yang perlu dihindari adalah masyarakat tidak lagi percaya terhadap kebenaran informasi yang disampaikan oleh suatu media, dan ketika masyarakat sudah tidak mau lagi mengonsumsi media tersebut maka mereka segera beralih pada media yang dianggapnya bisa dipercaya

Jurnalisme online sebaiknya tidak dipandang sebatas bagaimana jurnalis memanfaatkan berbagai platform digital untuk menyebarkan informasi dan pesan. Tapi juga bagaimana jurnalis online memiliki kesadaran bahwa dalam memburu informasi untuk kemudian diolah menjadi berita hendaknya sudah memenuhi aspek dari prinsip jurnalistik, nilai-nilai dan elemen jurnalistik sebagaimana yang masih ditegakkan oleh media berita konvensional karena semua hal tersebut memiliki pertanggung jawaban yang berlaku. Dari sudut pandang ini, jurnalisme online bisa dielaborasi lagi dengan konsep jurnalisme data. Elaborasi lebih luas atas konsep jurnalisme online supaya bisa mencakup aktivitas dari hulu sampai ke hilir menjadi suatu hal yang penting. Upaya ini tak lain untuk mencegah terjadinya penyempitan makna praktik jurnalisme, supaya praktik jurnalisme tidak sekadar dilihat sebagai aktivitas diseminasi informasi saja. Berlimpahnya data di jejaring sosial akan menjadi bahan berguna bagi jurnalis untuk diolah menjadi informasi yang bermakna bagi publik.

\section{DAFTAR PUSTAKA}

Abadi, H. S. (2019). Media Sosial dan Antitesis Jurnalisme: Socialmedia and Journalism Antithesis. Jurnal Spektrum Komunikasi. 7 (1). 17-29. http://spektrum.stikosaaws.ac.id.

Ashari, M. (2019). Jurnalisme Digital: Dari Pengumpulan Informasi Sampai Penyebaran Pesan. Inter Komunika; Jurnal Ilmu Komunikasi. 4 (1). 1-16. https://journal.interstudi.edu/index.php/InterKomunika

Apuke, OD. (2017). Another Look at the Political Economy of the Mainstream and New Media: The Capitalists Influence. Journal of Mass Communication and Journalism. 7 (4): 341 $-348$.

Baran, S.J., dan Davis, D.K. (2010). Teori Komunikasi Massa: Dasar, Pergolakan, dan Masa Depan, edisi lima, terjemahan Afrianto Daud dan Putri Iva Izzati, Jakarta: Salemba Humanika

Barthel, M. (2018). Despite Subscription Surges for Largest U.S. Newspapers, Circulation and Revenue Fall for Industry Overall. Pew Research Center. Retrieved from https://pewrsr.ch/2qFfi3q

Bashori, K. (2018). Pendidikan Politik di Era Disrupsi. Sukma: Jurnal Pendidikan. Vol 2 (2). 287-310. https://www.jurnalsukma.org/index.php/sukma/article/view/02207.2018/40

Burnett, R. and Marshall, P.D. (2003). Web Theory: An Introduction. London: Routledge.

Bruno, N. (2011). Tweet first, verify later? How real-time information is changing the coverage of worldwide crisis events. Reuters Institute for the Study of Journalism. Retrieved from https://bit.ly/2Fuiztg

Dwyer, T. (2010). Media Convergence. UK: McGraw Hill Open University Press.

Doyle, A. (2018). 12 Worst Jobs in America. The Balance Careers. Retrieved from https://bit.ly/2SoOEFq

Foust, J. C. (2011). Online Journalism: Principles and Practices of News for the Web. 3rd ed. Scottsdale, Ariz: Holcomb Hathaway Publishers. 


\section{PROPAGANDA}

Fuchs, C. dan Marisol, S. (2015). The Political Economy of Capitalist and Alternative Socialmedia. In Chris Atton (eds). The Routledge Companion to Alternative and Community Media. London: Routledge.

Fuchs, C. dan Marisol, S. (2015). Culture and Economi in The Age of Socialmedia, London and New York: Routledge.

Gehl, R. W. (2015). The Case for Alternative Socialmedia. Social Media + Society. 1- 12.

Hutomo, M. S. (2020). Bertahan Untuk Hidup: Konvergensi Pers Cetak Dalam Industri Digital Media. Caraka: Indonesian Journal of Communications, 1 (1), 30-37. https://doi.org/10.25008/caraka.v1i1.40

Jenkins, H. (2006). Convergence Culture; Where Old and New Media Collide. USA: New York University Press.

Jurnal Ilmu Komunikasi. 9 (1). 26-39. http://jurnal.unpad.ac.id/jkk.

Kovach, B., dan R. (2004). Elemen-Elemen Jurnalisme, Institut Studi Arus Informasi (ISAI), Jakarta

Kriyantono, R. (2010). Teknik Praktis Riset Komunikasi: Disertai Contoh Praktis Riset Media, Public Relations, Advertising, Komunikasi Organisasi, Komunikasi Pemasaran. Jakarta: Kencana Prenada Media Group.

Malik, A., \& Shapiro, I. (2017). What's digital? What's journalism? In B. Franklin \& S. Eldridge II (Eds.), The Routledge companion to digital journalism studies (pp. 15-24). Milton Park, Abingdon: Routledge.

Margianto, H. J., dan Syaefullah, A. (2014). Media Online: Pembaca, Laba, Etika (Problematika Praktik Jurnalisme Online di Indonesia). Jakarta: AJI Indonesia.

McQuail, D. (2005). Mass Communication Theory (5th Edition). London: SAGE Publication Ltd.

McQuail, D. (1992). Media Performance: Mass Communication and the Public Interest. London: Sage Publications

Mencher, M. (2000). News Reporting and Writing (ninth edition). Boston: McGraw Hill

Meyer, P. (2009). The Vanishing Newspaper: Saving Journalism in The Information Age. University of Missouri Press.

Muliawati, L. (2018). Jurnalisme Era Digital: Digitalisasi Jurnalisme dan Profesionalitas Jurnalisme Online. Jurnal Lentera. 2 (1). 79-98. https://journal.iainsamarinda.ac.id/index.php/lentera/article/view/1168

Pangaribuan, O. C., \& Irwansyah, I. (2019). Media Cetak Indonesia di Era Revolusi Industri 4.0. Jurnal Pewarta Indonesia, 1 (2), 119-130. https://doi.org/10.25008/jpi.v1i2.11 Prasad, Revati. (2021). Digital disruption? Journalism startups in India. SAGE Journals. 22(8). 2122-2138. https://journals.sagepub.com/toc/joua/22/8

Priyambodo, RH. (2008) "Ranjau-Ranjau dan Kode Etik Jurnalis Online", makalah pada Lokakarya Kode Etik Jurnalistik untuk Praktisi Media di Lembaga Pers Dr. Soetomo/LPDS dan Dewan Pers, Jakarta.

Putra, R, A. (2019). Tantangan Media Massa Dalam Menghadapi Era Disrupsi Teknologi Informasi. Jusinfo: Jurnal Sistem Informasi. 5 (1). 1-6. http://jurnal.radenfatah.ac.id/index.php/jusifo/issue/view/468

Rahayu (ed.). (2006). Menyingkap Kinerja Surat Kabar di Indonesia. Yogyakarta: PKMBP, Dewan Pers, dan Menkominfo

Rianto, P. (2007). Pers Indonesia Kontemporer: Antara Profesionalisme dan Tanggung Jawab Sosial, Yogyakarta: PKMBP.

Romli., dan Asep, S. M. (2018). Jurnalistik Online: Panduan Mengelola Media Online. Bandung: Nuansa Cendikia.

Ritonga, R. (2021). Rontoknya Independensi Pers Cetak dan Online di Kota Medan. 
Sewchurran, A. and Benda, H. yang berjudul, (2020). A Critical Reflection on Digital Disruption in Journalism and Journalism Education. Acta Academica. (Bloemfontein, Online). Vol.52 n.2 Bloemfontein.

Shapiro, I., Brin, C., Bedard-Brule, I. And Mychajlowycz, K. (2013). Verification as a Strategic Ritual. Journalism Practice 7 (6): 657-673.

Shoemaker, P. J. \& Reese, S. D. (1996). Mediating the Message: Theories of Influences on Mass Media Content. Second Edition. New York: Longman

Syahputra, I. (2013). Rezim Media Pergulatan Demokrasi, Jurnalisme, dan Infotainment dalam Industri Televisi. Jakarta: Gramedia Pustaka Utama.

Tandoc, E.C. (2019). Analyzing Analytics Disrupting Journalism One Click at a Time. London and New York: Routledge.

Tandoc, E.C. (2018). Singapore. Reuters Institute Digital News Report. Retrieved from https://bit.ly/2DEQrBQ.

Tandoc, E., \& Vos, T. P. (2016). The journalist is marketing the news: Socialmedia in the gatekeeping process. Journalism Practice, 10(8), 950-966. doi: 10.1080/17512786.2015.1087811

Tapsell, R. (2017). Media Power in Indonesia, Oligarchs, Citizens and the Digital Revolution. London: Rowman \& Littlefield.

Tomacruz, S. (2017). Fast Facts: What You Should Know About the Inquirer Group. Rappler.

\section{Sumber Online} Retrieved from https://bit.1y/2KNe1y7

https://cakrawala.co/menyikapi-banjir-informasi-di-ruang-digital/ diunduh tanggal 07 Agustus 2021.

https://dewanpers.or.id/publikasi/opini_detail/173/Media_Online_Perlu_Berbenah_Diri, diunduh tanggal 07 Agustus 2021.

https://www.suara.com/bisnis/2020/08/25/181636/media-cetak-mulai-ditinggalkanmasyarakat-beralih-ke-media-online, diunduh tanggal 07 Agustus 2021.

https://nasional.kompas.com/read/2021/08/05/13295161/kisah-sumbangan-rp-2-triliun-dariakidi-tio-dan-kecerobohan-para-pejabat?page=all, diunduh tanggal 08 Agustus 2021.

https://www.liputan6.com/bisnis/read/4619135/dahlan-iskan-kapolda-sumsel-pusing-terimasumbangan-keluarga-akidi-tio-rp-2-triliun?source=search, diunduh tanggal 08 Agustus 2021.

https://www.urbanasia.com/keluhkan-obat-covid19-kosong-saat-blusukan-jokowi-teleponmenkes-U37755, diunduh tanggal 08 Agustus 2021.

https://tekno.kompas.com/read/2021/02/23/11320087/berapa-lama-orang-indonesia-aksesinternet-dan-medsos-setiap-hari-?page=all\#page2. diunduh tanggal 09 Agustus 2021

https://kumparan.com/kumparantech/berapa-lama-orang-indonesia-pakai-internet-setiap-hari$\underline{1 \mathrm{sm} 180 \mathrm{YziOQ} / \text { full, }}$ diunduh tanggal 09 Agustus 2021. 